Article

\title{
Extraction of Oil and Minor Compounds from Oil Palm Fruit with Supercritical Carbon Dioxide
}

\author{
Huan Phan Tai ${ }^{1, *(\mathbb{D})}$ and Gerd Brunner ${ }^{2}$ \\ 1 Faculty of Food Science and Technology, Nong Lam University, Ho Chi Minh City 700000, Vietnam \\ 2 Institute of Thermal and Separation Processes, Hamburg University of Technology, Eissendorfer Strasse 38, \\ D-21073 Hamburg, Germany; brunner@tuhh.de \\ * Correspondence: pthuan@hcmuaf.edu.vn; Tel.: +84-28-38966780
}

Received: 19 January 2019; Accepted: 13 February 2019; Published: 18 February 2019

check for updates

\begin{abstract}
A significant quantity of tocochromanols and carotenoids remains in the residual from palm oil production by traditional screw pressing. Supercritical carbon dioxide extraction was used as alternative method with the purpose to recover better these valuable minor compounds. Total oil yield and co-extracted water were investigated in the course of extraction. Tocochromanols and carotenoids were evaluated, not only in the extraction oil, but also in the oil of residual fibre. Modelling of extraction process was also performed for a further up-scaling. The results showed that oil yield up to $90 \%$ could be observed within $120 \mathrm{~min}$. Supercritical carbon dioxide $\left(\mathrm{SCCO}_{2}\right)$ could extract tocochromanols and carotenoids with concentration in the same range of normal commercial processing palm oil, while co-extracted water remained rather low at a level of $2-4 \%$. Moreover, recovery efficiencies of these minor compounds were much higher in case of extraction processed with supercritical carbon dioxide than those with screw pressing method.
\end{abstract}

Keywords: supercritical extraction; tocopherols; tocotrienols; carotenoids; modelling

\section{Introduction}

Palm oil is well known all over the world because of its high quality. According to Tan 2012 [1], palm oil has a balanced fatty acid composition in which the level of saturated and unsaturated fatty acids are almost equal with $50 \%$ saturated, $40 \%$ monounsaturated and $10 \%$ polyunsaturated fatty acids. As a consequence of high polyunsaturated acid content, palm oil is a good oil with the ability to reduce blood cholesterol and the risk of coronary heart disease. Besides, palm oil contains ca. $3 \%$ of free fatty acids and $1 \%$ of other minor components. The minor constituents of palm oil include carotenoids, tocopherols, sterols, phosphatides, triterpenic and aliphatic alcohols. Among them, the most important compounds are carotenoids and tocochromanols (tocopherols and tocotrienols). Phoon et al. reported that crude palm oil contains 500-700 ppm of carotenoids and 1000-1200 ppm tocochromanols [2]. Carotenoids of palm oil are mainly in the form of alpha- and beta-carotenes, the precursor of vitamin A. The presence of these carotenes plays an important role in oxidative protection to the oil. On the other hand, the major portions of total tocochromanols in palm oil are alpha-tocopherol and gamma-tocotrienol. These compounds are also antioxidants and provide some natural oxidative protection to the oil. It is obvious that the combination effects of properties of carotenoids, tocochromanols and high portion of unsaturated acids give palm oil a higher oxidative stability compared to many other edible oils. However, these carotenoids are thermally destroyed during the deodorization stage [3]. Therefore, a lot of new and improved methods for palm oil production have been investigated and applied during the last decades.

Up to now, recovery of oil from the mesocarp of palm fruits by using crew pressing system is the most commonly used method [4]. However, a significant quantity of carotenoids (3800-7000 ppm) 
and tocochromanols (1900-3000 ppm) remain in the residual oil (5-6\% on dry basis) in the palm press fibres [2,5]. Recently, supercritical fluid technology has been proven to be a modern technique for extraction and reaction [6,7]. Supercritical $\mathrm{CO}_{2}$ has been applied in extraction, purification and fractionation of crude palm oil [8-11]. Direct extraction of palm oil from palm pulp or kernel under supercritical condition has been conducted [12-15]. Besides, the waste from palm oil processes like pressed palm fibre [16-19] was also investigated. In general, extraction of palm oil from palm fruit and pressed fibre using supercritical fluid extraction has been explored. However, a full investigation about total oil yield, co-extracted water, carotenoids and tocochromanols in the extracted and the residue oil in a single run has not been fully reported. Recently palm oil has become a starting material to produce natural tocochromanols and carotenoids $[5,9,20]$. Therefore, the objective of the following study was to prove that using supercritical $\mathrm{CO}_{2}$ as extraction solvent will bring more benefit in point of view to better recover these valuable minor compounds. The work included a study of extraction of palm mesocarp by supercritical $\mathrm{CO}_{2}$ at different pressure, temperature and flow rate. Total oil yield and co-extracted water were investigated in the course of extraction. Tocochromanols and carotenoids were evaluated not only in the extraction oil but also in the oil of residual fibre. Modelling of extraction process was also performed for a further up-scaling.

\section{Materials and Methods}

\subsection{Materials}

Hexane and butyl methyl ether (HPLC grade), acetone (>99.8\%), Hydranal-Composite 5 were purchased from Lab-Scan (Dublin, Ireland), Sigma (Saint-Quentin Fallavier, France), Prolabo (Fontenay-sous-Bois, France) and Riedel-de Häen (Seelze, Germany), respectively. Standards were supplied by Merck (Darmstadt, Germany).

Palm fruit (Elaeis guineensis) was from Malaysia. The fruits were separated into skin, mesocarp and kernel. The yellow part of the mesocarp is investigated. The average particle size of the pulp for supercritical extraction was about $1 \times 2 \times 6(\mathrm{~mm} \times \mathrm{mm} \times \mathrm{mm})$.

\subsection{Equipment and Experiment Procedure}

A standardized supercritical extraction system, developed at the Institute for Thermal and Separation Processes-at the Hamburg University of Technology (TUHH), was used. The simplified flow sheet is shown as Figure 1. Liquefied $\mathrm{CO}_{2}$ (purity of 99.95\%) from the reservoir tank were pumped by a Maximator pump (max. $600 \mathrm{bar}$ ) to the $100 \mathrm{~mL}$ steel extractor cell, which was loaded with $14.5 \mathrm{~g}$ of palm mesocarp (fixed bed) for each run. The system was monitored at the investigated pressure (200-400 bar) and temperature $\left(45-65^{\circ} \mathrm{C}\right)$ with the specific flow rate from 14 to $56 \mathrm{~kg} \mathrm{~h}^{-1}$ of gas per $\mathrm{kg}$ of sample. The extracts were collected continuously in $10 \mathrm{~mL}$ glass vials, used as sample collectors at atmospheric pressure.

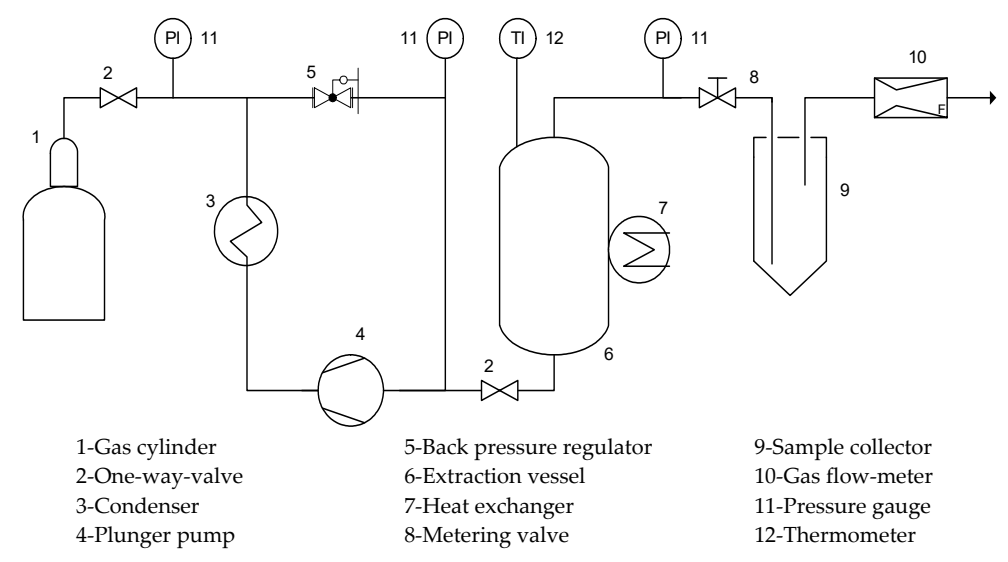

Figure 1. Flow-sheet of the extraction unit. 


\subsection{Analytical Method}

(a) High Performance Liquid Chromatography (HPLC)

A HPLC system from Gynkotek with RF 1002 Fluorescent detector was used for analysis. Tocopherols and tocotrienols in the oil samples were separated on a LiChrosorb Diol, $5 \mu \mathrm{m}, 250 \times 4.6 \mathrm{~mm}$ column (Chrompack $\mathrm{N}^{\circ}$ 612834). The mobile phase was hexane (96\%) and butyl-methyl-ether (4\%) at a flow rate of $1300 \mu \mathrm{L} / \mathrm{min}$. Injection volume was $20 \mu \mathrm{L}$. External standard curves were used to determine tocochromanols content in the oil samples.

(b) UV-Vis Spectroscopy

UV-Vis Spectroscopy (spectrometer UV-120-02 from Shimadzu, Kyoto, Japan) was used to determine the content of carotenoids in the analysed samples. For a measurement, an amount of 10 to $20 \mathrm{mg}$ of oil sample is diluted with $2 \mathrm{~mL}$ mixture of acetone and hexane (30:70 by Vol.\%). The absorbance was recorded at the wavelength of $450 \mathrm{~nm}$ and compared with the standard curve determined with a series of samples with a known amount of $\beta$-carotene.

(c) Soxhlet extraction

A Soxhlet extraction was used to extract the total oil of the original palm mesocarps and the residual fibres. Hexane was used as the extraction solvent. The extraction time was $8 \mathrm{~h}$.

(d) Karl-Fischer water titration

Dead-Stop Titrator TR 52 (Schott, Hofheim, Germany) was used to determine the water concentration from the supercritical extracts. Hydranal-Composite 5 were used as titrating agents. To obtain the water content, first the titre number was determined regularly by titrating known amounts of distilled water.

$$
\text { Titer }=\frac{m_{\mathrm{H}_{2} \mathrm{O}}}{V_{T}}
$$

where $m_{H 2 O}$ : amount of water in $\mathrm{mg} ; V_{T}$ : volume the titrant in $\mathrm{mL}$.

The titrating solutions had a water equivalent of approximately $5 \mathrm{mg} \mathrm{H} \mathrm{H}_{2} \mathrm{O} / \mathrm{mL}$. Water content $(\%)$ in the samples was finally determined as:

$$
\mathrm{H}_{2} \mathrm{O}(\%)=\frac{V_{T} \times \text { Titer } \times 100}{m_{P}}
$$

where $m_{P}$ : amount of sample in $\mathrm{mg}$.

(e) Extraction modelling

In this study, the Supercritical carbon dioxide $\left(\mathrm{SCCO}_{2}\right)$ extraction of palm fruit process is described by applying the VTII-Model for the extraction from solids using supercritical solvents [21].

\section{Results and Discussion}

\subsection{Effect of Process Parameters on Batch Extraction}

Solubility of a compound in a dense fluid varies with pressure and temperature which can change fluid density and solvent power. Figure 2 shows that total palm oil yields are significantly affected by the pressure and temperature applied. At $65^{\circ} \mathrm{C}$ and specific flow rate of $35 \mathrm{~kg} \mathrm{~h}^{-1} \mathrm{~kg}^{-1}$, increasing pressure from 300 to 400 bar increased the total oil yield from 80 to $92 \%$ after 120 min of extraction. In general, it is observed that the extraction yield increases with higher pressure at any temperature. On the other hand, at a high pressure (300 or 400 bar), extraction yield increases with higher temperature. This phenomenon has been reported in $\mathrm{SCCO}_{2}$ extraction of other oil [22]. It can be explained by the fact that effect on palm oil vapor pressure is more pronounced than effect of decreasing solubility when changing extraction temperature.

The flow rate is another factor, which affects total oil recovery and the mass transfer inside the palm pulp. It is observed that an increase in flow rate will increase the amount of the collected oil, therefore shorten the extraction time. However, a balance between additional oil recovery and extra cost should be considered in the economical point of view. Brunner [21] pointed out that a high 
solvent ratio causes enhanced operating costs and higher capital costs, because the equipment is more expensive due to its larger size.

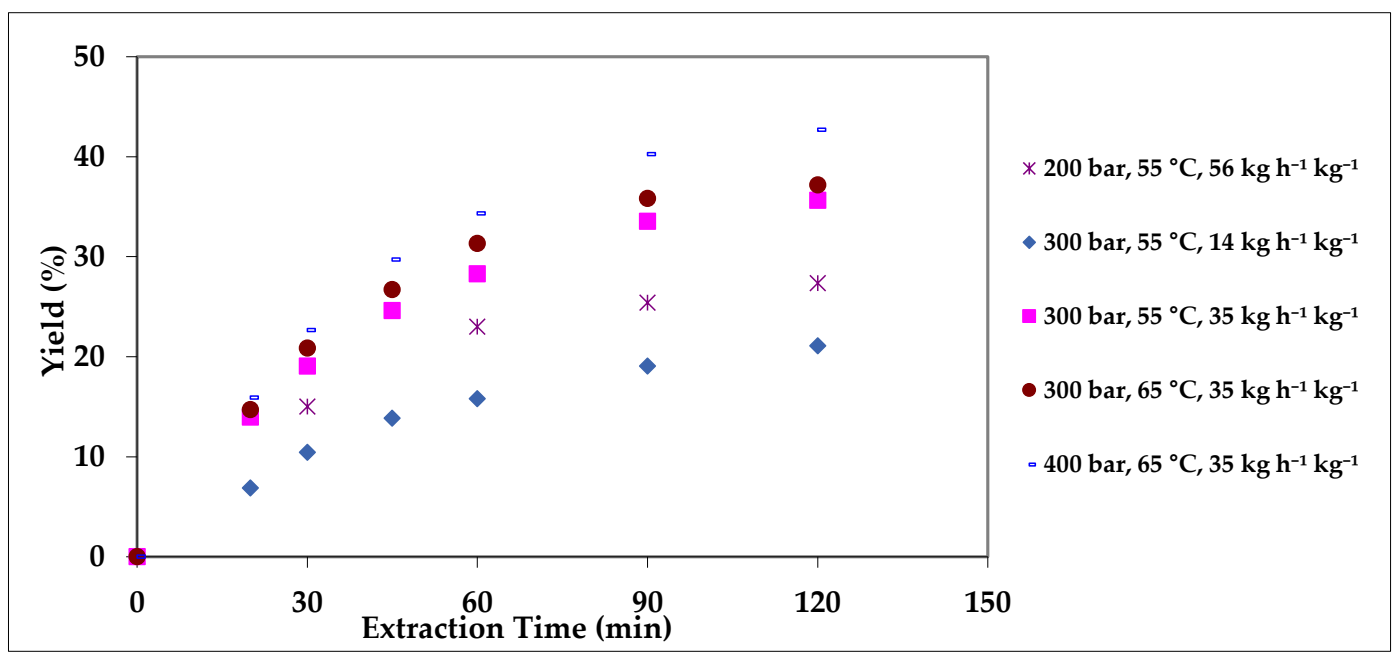

Figure 2. Extraction of palm oil from mesocarp with $\mathrm{SCCO}_{2}$.

It can be concluded that the extraction was not sufficient for oil recovery at 200 bar, even with a very high flow rate. At a high pressure, $\mathrm{SCCO}_{2}$ at 400 or 300 bar with a specific flow rate of $35 \mathrm{~kg} \mathrm{~h}^{-1} \mathrm{~kg}^{-1}$, palm oil could be recovered up to $60-70 \%$ after $60 \mathrm{~min}$ of extraction or $80-90 \%$ after $120 \mathrm{~min}$. In other work, Lau et al. obtained $77.3 \%$ oil yield at 300 bar and $80{ }^{\circ} \mathrm{C}$ [12].

\subsection{Co-Extracted Water during $\mathrm{SCCO}_{2}$ Extraction}

Water is always found in natural plant products. The studied palm mesocarp contained ca. $20 \%$ of water. Among the investigated fluids, $\mathrm{SCCO}_{2}$ has ability to dissolve a small amount of water [23,24]. Therefore, knowledge about co-extracted water with palm oil in $\mathrm{SCCO}_{2}$ is required. Figures 3 and 4 show the amount of water and oil co-extracted by $\mathrm{SCCO}_{2}$ at 300 and 400 bar and at different temperatures. In extraction pressure and temperature ranges of the experiments, the extracted oil had only ca. $2-4 \%$ water content. That value is rather small. Crude palm oil, extracted from palm fruit by pressing, contains more than $10 \%$ water with impurities consisting of vegetable matter [25]. As a consequence, the process for removing water from palm oil can be reduced.

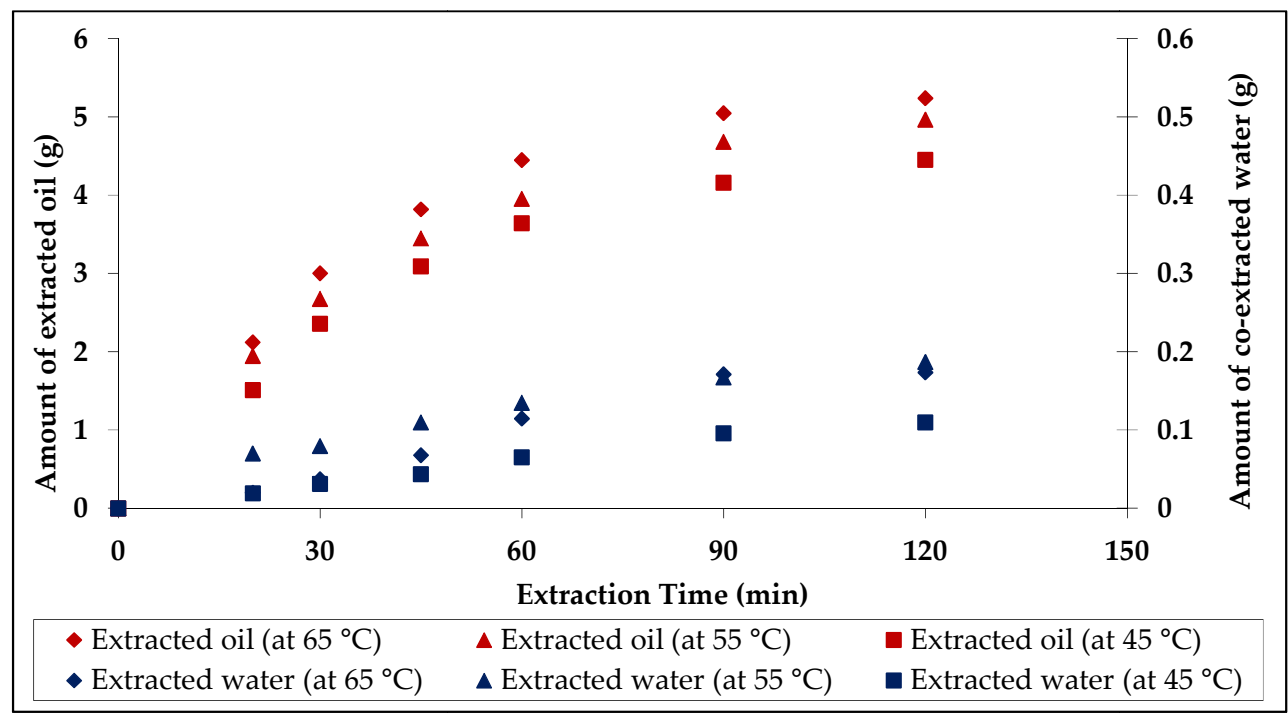

Figure 3. $\mathrm{SCCO}_{2}$ extraction of oil and water at $300 \mathrm{bar}, 35 \mathrm{~kg} \mathrm{~h}^{-1} \mathrm{~kg}^{-1}$ with $14.5 \mathrm{~g}$ of palm mesocarp. 


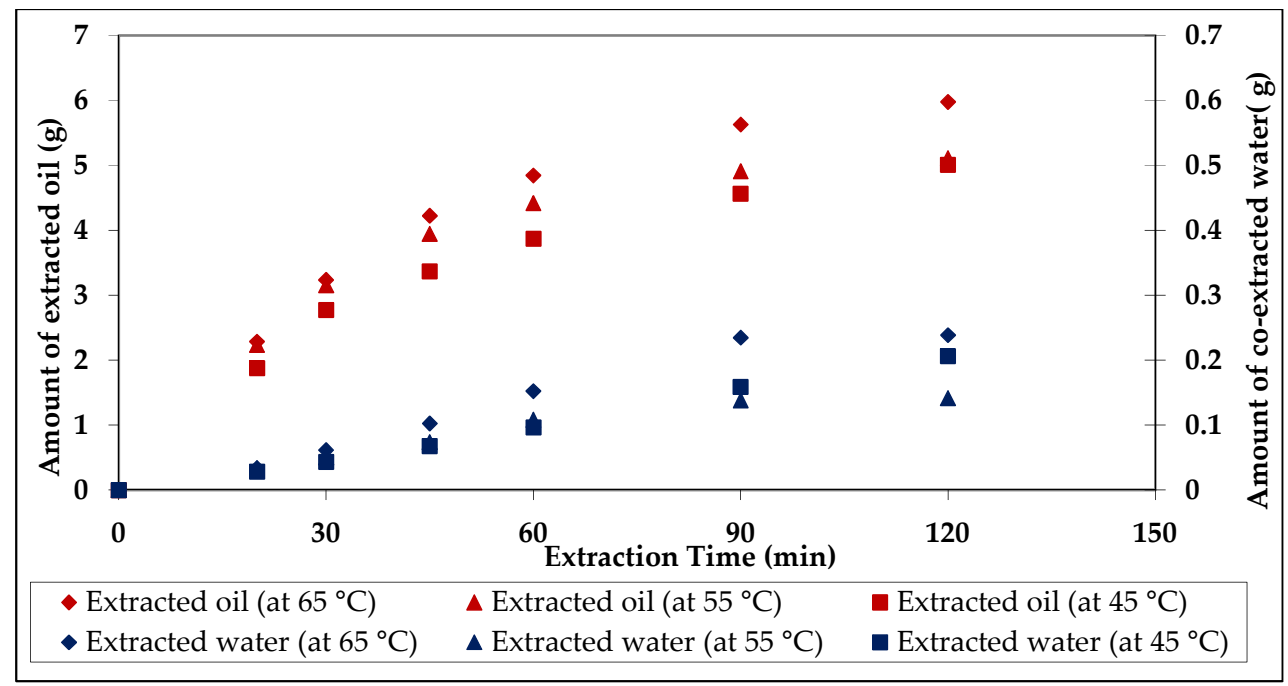

Figure 4. $\mathrm{SCCO}_{2}$ extraction of oil and water at $400 \mathrm{bar}, 35 \mathrm{~kg} \mathrm{~h}^{-1} \mathrm{~kg}^{-1}$ with $14.5 \mathrm{~g}$ of palm mesocarp.

\subsection{Tocochromanols and Carotenoids Extraction}

Tocochromanols and carotenoids are interesting valuable minor components in supercritical fluid extraction $[9,20]$. It was shown that the amount of carotene extracted from the residue from mechanical processing of palm oil is not high enough to allow an economic industrial size $\mathrm{SCCO}_{2}$ extraction [26]. Therefore, efficient recovery of these compounds during oil extraction by $\mathrm{SCCO}_{2}$ alternatively is expected. Concentrations of tocochromanols and carotenoids in the extracted oil depend on their solubilities and those of the other compounds at the same time. Figure 5 shows how a concentration of carotenoids changes with extraction time using $\mathrm{SCCO}_{2}$. Different fractions at different extraction time (20-30 $\mathrm{min}, 45-60 \mathrm{~min}, 60-90 \mathrm{~min}$ and 90-120 $\mathrm{min}$ ) were analysed. It is observed that at a low pressure (200 bar), carotenoids content increased with extraction time. This agrees with results reported in the extraction of crude palm oil at a similar condition [8]. Therefore, it is also suggested that palm oil can be separated into different carotenoids fractions at the pressure of $200 \mathrm{bar}$, although carotenoids is not well soluble in $\mathrm{SCCO}_{2}$. In contrast, at a higher pressure (300 or 400 bar), the carotenoids concentration remains constant. The fractionated oil can reach the same carotenoids value as in commercial crude palm oil. This agrees with the conclusion from Lau et al. for $\mathrm{SCCO}_{2}$ extraction of dried palm fruits [12]. However, the residual oil contains fewer minor compounds than in a screw pressing process.

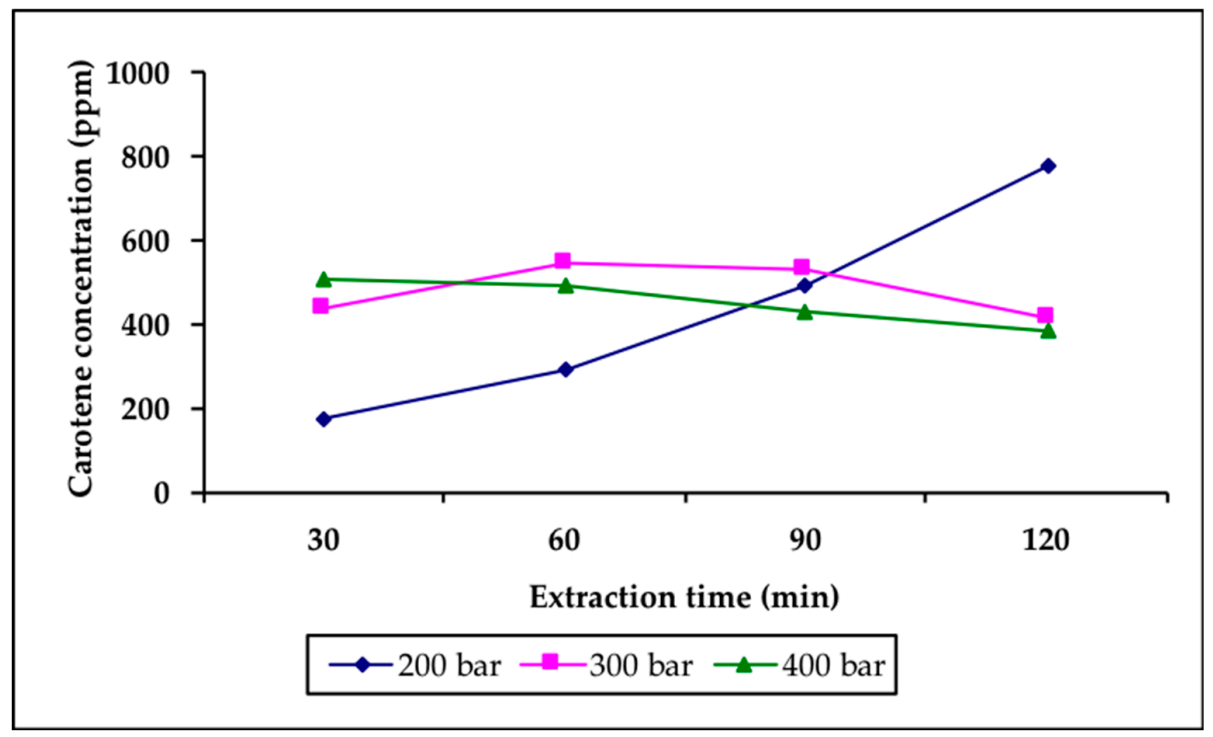

Figure 5. Carotenoids as extracted with $\mathrm{SCCO}_{2}$ at $45^{\circ} \mathrm{C}$ and $14 \mathrm{~kg} \mathrm{~h}^{-1} \mathrm{~kg}^{-1}$. 
As shown in Figure 6, there is different behaviour in tocochromanols and carotenoids extraction with $\mathrm{SCCO}_{2}$. Besides, the composition of palm mesocarp varies with the size and the age of palm fruits. Thus, to objectively evaluate the efficiency of recovery of tocochromanols and carotenoids by using different supercritical extraction conditions (after 120-min extraction time), a relative comparison of the concentration of these compounds in extracted oil and residue oil was used with enrichment factor $K$ (Table 1). Enrichment factor $K$ of component $X$ is defined as following equation:

$$
K(X)=\frac{\text { concentration_of_component_X_in_the_extracted_oil }}{\text { concentration_of_component_X_in_the_residue_oil }}
$$

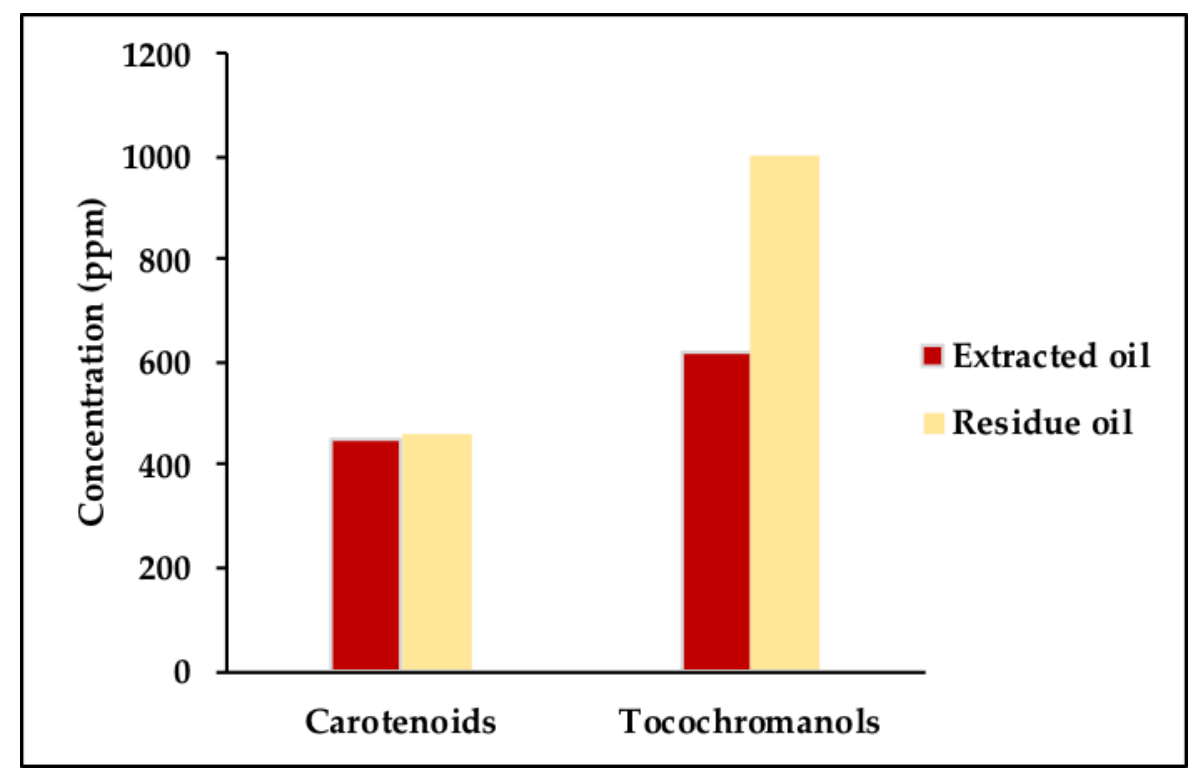

Figure 6. Concentration of carotenoids and tocochromanols in extracted and residue oils by $\mathrm{SCCO}_{2}$ extraction at $400 \mathrm{bar}, 55^{\circ} \mathrm{C}, 35 \mathrm{~kg} \mathrm{~h}^{-1} \mathrm{~kg}^{-1}$.

Table 1. Enrichment factors of tocochromanols and carotenoids with different extraction techniques.

\begin{tabular}{|c|c|c|c|}
\hline Technique & Temp. $\left({ }^{\circ} \mathrm{C}\right)$ & K (Carotenoids) & K (Tocochromanols) \\
\hline \multirow[t]{3}{*}{$\mathrm{SCCO}_{2} 300$ bar } & $45^{\circ} \mathrm{C}$ & 0.79 & 0.67 \\
\hline & $55^{\circ} \mathrm{C}$ & 1.21 & 0.41 \\
\hline & $65^{\circ} \mathrm{C}$ & 0.79 & 0.41 \\
\hline \multirow[t]{3}{*}{$\mathrm{SCCO}_{2} 400$ bar } & $45^{\circ} \mathrm{C}$ & 1.19 & 0.54 \\
\hline & $55^{\circ} \mathrm{C}$ & 0.98 & 0.62 \\
\hline & $65^{\circ} \mathrm{C}$ & 0.90 & 0.86 \\
\hline \multicolumn{2}{|c|}{$\begin{array}{l}\text { Screw pressing } \\
\text { calculated after Phoon et al. [2] }\end{array}$} & ca. 0.11 & ca. 0.45 \\
\hline
\end{tabular}

As a result, the extraction technique with a higher value of $K(X)$ gives a better potential to recover component $X$.

The results show that much more tocochromanols and carotenoids can be recovered by using $\mathrm{SCCO}_{2}$ than by traditional screw pressing. It has been reported that extractions of carotenoids and tocochromanols from fibre residues were not high enough for a possible industrial application. Supercritical $\mathrm{CO}_{2}$ extraction of palm oil, simultaneously recovering its high valuable minor components from the palm fruits could open a new way for an alternative extraction method. 


\subsection{Mathematical Extraction Modelling}

The so-called VT II model [21] integrates a complete mass transfer to a fluid phase side. Additionally, solid particles are considered as simple spheres with a mean diameter. A linear driving force due to the differences of concentration from the solid to the fluid phase is assumed. This model was previously used for the simulation of $\mathrm{SCCO}_{2}$ extraction of oil from rice bran [27]. Equations (4) to (9) present the key equations of the model [21].

Mass balance for the fluid phase is:

$$
\frac{\partial c_{F}}{\partial t}=D_{a x} \cdot \frac{\partial^{2} c_{F}(z)}{\partial z^{2}}-\frac{u_{z}}{\varepsilon} \cdot \frac{\partial c_{F}(z)}{\partial z}-\frac{1-\varepsilon}{\varepsilon} \cdot \frac{\partial \bar{c}(z)}{\partial t}
$$

And mass balance for the solid phase is:

$$
\frac{\partial \bar{c}(z)}{\partial t}=a \cdot k_{\mathrm{oG}} \cdot\left(c_{F}(z)-\bar{c}_{S}(z) \cdot \frac{K\left(\bar{c}_{S}\right)}{\rho_{S}}\right)
$$

Equilibrium of substrate between fluid phase and solid phase could be written:

$$
\begin{gathered}
K\left(\bar{c}_{s}\right)=\frac{c_{F}^{*}}{\bar{c}_{s}} \\
K\left(\bar{c}_{s}\right)=k_{1} \cdot \bar{c}_{s} \exp ^{-k_{2}}
\end{gathered}
$$

And the overall mass transfer coefficient could be expressed as:

$$
\begin{gathered}
\frac{\beta_{F}}{k_{o G}}=1+\frac{B i \cdot K\left(\bar{c}_{s}\right)}{6} \\
B i=\frac{\beta_{F} R K}{D_{e s}}
\end{gathered}
$$

where:

$\bar{c}_{S}=$ mean concentration of extract components in the solid phase

$c_{F}=$ concentration of extract in the fluid

$D_{a x}=$ axial dispersion coefficient

$u_{z}=$ void volume linear velocity of supercritical solvent

$c_{f}^{*}=$ equilibrium concentration of extract in the fluid phase

$K=$ equilibrium distribution coefficient between liquid and solid phase

$D_{e s}=$ effective diffusion coefficient in the solid phase

$k_{O G}=$ overall mass transfer coefficient for the gas phase

$z=$ coordinate in axial direction

$\varepsilon=$ porosity of the fixed bed

$t=$ time of extraction

$a=$ specific surface of solid phase

$\rho_{s}=$ density of the solid material

$k_{1}, k_{2}=$ coefficients of the sorption isotherm (Freundlich's isotherm)

$\beta_{F}=$ mass transfer coefficient for the fluid phase

$R=$ solid particle's diameter

By least-square fitting of the experimental data, the process parameters for diffusion, desorption and dispersion could be estimated. The fitted parameters, together with characteristic dimensionless numbers are presented in Table 2. It is observed that the mass transfer coefficient for the fluid phase $\beta_{F}$ increases with increasing temperature. While, a higher axial dispersion coefficient $D_{a x}$ tends to be achieved at a lower temperature. It is also shown that Reynolds number increases with temperature 
but decreases with pressure. A higher temperature increases kinetic energy of the fluid affecting the fluid moving and direction. In contract, an increase in pressure directly relates to the increasing in solvent density and viscosity, resulting in a lower Reynolds number.

Table 2. Parameters fitted for SFE of palm mesocarp with the VTII model.

\begin{tabular}{cccccccc}
\hline Parameter & Unit & $\begin{array}{c}\mathbf{4 0 0} \mathbf{~ b a r}, \\
\mathbf{6 5}{ }^{\circ} \mathbf{C}\end{array}$ & $\begin{array}{c}\mathbf{4 0 0} \mathbf{~ b a r} \\
\mathbf{5 5}{ }^{\circ} \mathbf{C}\end{array}$ & $\begin{array}{c}\mathbf{4 0 0} \mathbf{~ b a r}, \\
\mathbf{4 5}{ }^{\circ} \mathbf{C}\end{array}$ & $\begin{array}{c}\mathbf{3 0 0} \mathbf{~ b a r}, \\
\mathbf{6 5}{ }^{\circ} \mathbf{C}\end{array}$ & $\begin{array}{c}\mathbf{3 0 0} \mathbf{~ b a r}, \\
\mathbf{5 5}{ }^{\circ} \mathbf{C}\end{array}$ & $\begin{array}{c}\mathbf{3 0 0} \mathbf{~ b a r} \\
\mathbf{4 5}{ }^{\circ} \mathbf{C}\end{array}$ \\
\hline$\varepsilon$ & - & 0.65 & 0.65 & 0.65 & 0.65 & 0.65 & 0.65 \\
$k_{1}$ & - & $3.10 \times 10^{-2}$ & $3.90 \times 10^{-2}$ & $4.20 \times 10^{-2}$ & $3.50 \times 10^{-2}$ & $3.10 \times 10^{-2}$ & $2.60 \times 10^{-2}$ \\
$k_{2}$ & - & $3.50 \times 10^{-1}$ & $2.90 \times 10^{-1}$ & $2.80 \times 10^{-2}$ & $2.90 \times 10^{-1}$ & $3.10 \times 10^{-1}$ & $3.30 \times 10^{-1}$ \\
$K$ & - & $8.43 \times 10^{-3}$ & $1.39 \times 10^{-2}$ & $3.79 \times 10^{-2}$ & $1.22 \times 10^{-2}$ & $1.24 \times 10^{-2}$ & $8.22 \times 10^{-3}$ \\
$D_{a x}$ & $\mathrm{~m}^{2} / \mathrm{s}$ & $5.56 \times 10^{-2}$ & $5.74 \times 10^{-2}$ & $9.61 \times 10^{-2}$ & $1.60 \times 10^{-1}$ & $1.64 \times 10^{-1}$ & $1.67 \times 10^{-2}$ \\
$\beta$ & $\mathrm{m}^{2} / \mathrm{s}$ & $3.73 \times 10^{-6}$ & $3.47 \times 10^{-6}$ & $1.32 \times 10^{-6}$ & $2.84 \times 10^{-6}$ & $2.61 \times 10^{-6}$ & $2.41 \times 10^{-6}$ \\
$R e$ & - & 6.65 & 6.07 & 5.52 & 7.89 & 7.08 & 7.08 \\
$S c$ & - & 1782 & 1988 & 2863 & 2674 & 3023 & 4961 \\
$S h$ & - & 6.09 & 6.09 & 6.09 & 6.09 & 6.08 & 6.09 \\
$B i$ & - & 0.18 & 0.30 & 0.42 & 0.33 & 0.27 & 0.23 \\
\hline
\end{tabular}

A comparison of experimental data with the calculated curves is presented in Figure 7. The results show that this model can be used to describe the palm oil extraction by $\mathrm{SCCO}_{2}$. The VTII model is fitting well the extracting curves and can also define the extracting process. This model has been successfully applied for the calculation of the extraction of theobromine with a scale up factor of 40 in a pilot plant [21]. Therefore, results can be used for an up-scaling purpose.

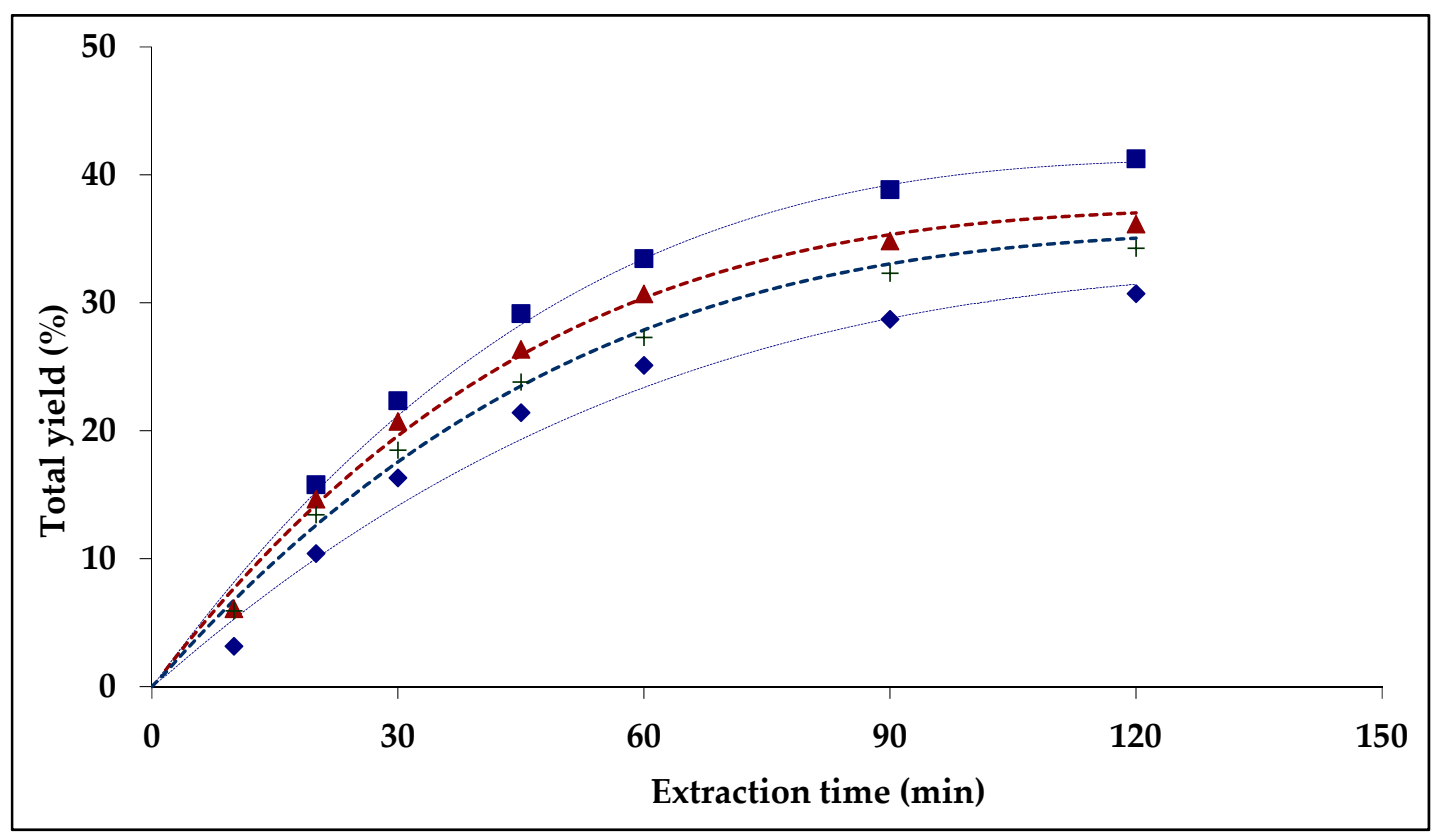

Figure 7. Comparison of experimental data with calculated curves at $35 \mathrm{~kg} \mathrm{~h}^{-1} \mathrm{~kg}^{-1}$. ( $) 300 \mathrm{bar}$, $45^{\circ} \mathrm{C}$; (+) 300 bar, $55^{\circ} \mathrm{C}(\boldsymbol{\Delta}) 300$ bar, $65^{\circ} \mathrm{C}$; ( $\left.\mathbf{\square}\right) 400$ bar, $65^{\circ} \mathrm{C}$; (.....) VTII model.

\section{Conclusions}

$\mathrm{SCCO}_{2}$ can be used to extract palm oil with a very small amount of water and co-extract valuable minor compounds with concentrations in the same range as a normal screw-pressing oil. Extraction of palm fruit with $\mathrm{SCCO}_{2}$ can be more advantaged, when the target is recovery of oil and valuable minor compounds like tocochromanols and carotenoids, compared to traditional mechanical pressing. The study showed that with a specific flow rate of $35 \mathrm{~kg} \mathrm{~h}^{-1} \mathrm{~kg}^{-1}$, oil could be recovered up to $60-70 \%$ after $60 \mathrm{~min}$ of extraction or $80-90 \%$ after $120 \mathrm{~min}$. Using supercritical $\mathrm{CO}_{2}$ can recover much more 
tocochromanols and carotenoids than using traditional screw pressing. VT II model was successfully applied for the calculation of overall extraction curves. The calculated model parameters can be applied for further up-scaling.

Author Contributions: Conceptualization, G.B. and H.P.T.; methodology, G.B. and H.P.T.; formal analysis, H.P.T.; investigation, H.P.T.; resources, G.B.; writing—original draft preparation, H.P.T.; writing—review and editing, G.B. and H.P.T.; visualization, H.P.T.; supervision, G.B.; project administration, G.B.; funding acquisition, G.B.

Funding: This research received no external funding.

Conflicts of Interest: The authors declare no conflict of interest.

\section{References}

1. Tan, C.-P.; Nehdi, I.A. The Physicochemical Properties of Palm Oil and Its Components. In Palm Oil; Lai, O.-M., Tan, C.-P., Akoh, C.C., Eds.; AOCS Press: Urbana, IL, USA, 2012; pp. 377-391.

2. Phoon, K.Y.; Ng, H.S.; Zakaria, R.; Yim, H.S.; Mokhtar, M.N. Enrichment of minor components from crude palm oil and palm-pressed mesocarp fibre oil via sequential adsorption-desorption strategy. Ind. Crops Prod. 2018, 113, 187-195. [CrossRef]

3. Tehlah, N.; Kaewpradit, P.; Mujtaba, I.M. Development of Molecular Distillation Based Simulation and Optimization of Refined Palm Oil Process Based on Response Surface Methodology. Processes 2017, 5, 40. [CrossRef]

4. Obibuzor, J.U.; Okogbenin, E.A.; Abigor, R.D. Oil Recovery from Palm Fruits and Palm Kernel. In Palm Oil; Lai, O.-M., Tan, C.-P., Akoh, C.C., Eds.; AOCS Press: Urbana, IL, USA, 2012; pp. 299-328.

5. Mba, O.I.; Dumont, M.-J.; Ngadi, M. Palm oil: Processing, characterization and utilization in the food industry-A review. Food Biosci. 2015, 10, 26-41. [CrossRef]

6. Knez, Ž. Enzymatic reactions in subcritical and supercritical fluids. J. Supercrit. Fluids 2018, 134, $133-140$. [CrossRef]

7. Patel, D.; Kellici, S.; Saha, B. Green Process Engineering as the Key to Future Processes. Processes 2014, 2, 311-332. [CrossRef]

8. Markom, M.; Singh, H.; Hasan, M. Supercritical $\mathrm{CO}_{2}$ fractionation of crude palm oil. J. Supercrit. Fluids 2001, 20, 45-53. [CrossRef]

9. Chuang, M.-H.; Brunner, G. Concentration of minor components in crude palm oil. J. Supercrit. Fluids 2006, 37, 151-156. [CrossRef]

10. Lee, W.J.; Tan, C.P.; Sulaiman, R.; Chong, G.H. Solubility of red palm oil in supercritical carbon dioxide: Measurement and modelling. Chin. J. Chem. Eng. 2018, 26, 964969. [CrossRef]

11. Iftikhar; Tan, H.; Zhao, Y. Enrichment of $\beta$-carotene from palm oil using supercritical carbon dioxide pretreatment-solvent extraction technique. LWT-Food Sci. Technol. 2017, 83, 262-266. [CrossRef]

12. Lau, H.L.N.; Choo, Y.M.; Ma, A.N.; Chuah, C.H. Characterization and supercritical carbon dioxide extraction of palm oil (Elaeis guineensis). J. Food Lipids 2006, 13, 210-221. [CrossRef]

13. Araujo, M.E.; Machado, N.T.; França, L.F.; Meireles, M.A.A. Supercritical extraction of pupunha (Guilielma speciosa) oil in a fixed bed using carbon dioxide. Braz. J. Chem. Eng. 2000, 17, 297-306. [CrossRef]

14. Rahman, N.N.A.; Hassan, M.N.; Omar, A.; Ibrahim, M.H.; Kadir, M.O.A. Dehulling and its effect on supercritical extraction of palm kernel oil. J. Chem. Eng. Jpn. 2001, 34, 407-410. [CrossRef]

15. Zaidul, I.S.M.; Norulaini, N.A.N.; Omar, A.K.M.; Smith, R.L., Jr. Supercritical carbon dioxide (SC-CO2) extraction of palm kernel oil from palm kernel. J. Food Eng. 2007, 79, 1007-1014. [CrossRef]

16. De Franca, L.F.; Meireles, M.A.A. Modeling the extraction of carotene and lipids from pressed palm oil (Elaes guineensis) fibers using supercritical $\mathrm{CO}_{2}$. J. Supercrit. Fluids 2000, 18, 35-47. [CrossRef]

17. Lau, H.L.N.; Choo, Y.M.; Ma, A.N.; Chuah, C.H. Quality of residual oil from palm-pressed mesocarp fiber (Elaeis guineensis) using supercritical CO2 with and without ethanol. J. Am. Oil Chem. Soc. 2006, 83, 893-898. [CrossRef]

18. Norulaini, N.N.A.; Ahmad, A.; Omar, F.M.; Banana, A.A.S.; Zaidul, I.S.M.; Kadir, M.O.A. Sterilization and extraction of palm oil from screw pressed palm fruit fiber using supercritical carbon dioxide. Sep. Purif. Technol. 2008, 60, 272-277. [CrossRef] 
19. Rahman, N.N.A.; Al-Rawi, S.S.; Ibrahim, A.H.; Nama, M.M.B.; Kadir, M.O.A. Supercritical carbon dioxide extraction of the residual oil from palm kernel cake. J. Food Eng. 2012, 108, 166-170. [CrossRef]

20. Gast, K.; Jungfer, M.; Saure, C.; Brunner, G. Purification of tocochromanols from edible oil. J. Supercrit. Fluids 2005, 34, 17-25. [CrossRef]

21. Brunner, G. Gas Extraction-An Introduction to Fundamentals of Supercritical Fluids and the Application to Separation Processes. In Topics in Physical Chemistry; Baumgärtel, H., Grünbein, W., Hensel, F., Eds.; Springer: Heidelberg, Germany, 1994.

22. Tai, H.P.; Kim, K.P.T. Supercritical carbon dioxide extraction of Gac oil. J. Supercrit. Fluids 2014, 95, 567-571. [CrossRef]

23. Sabirzyanov, A.N.; Ilin, A.P.; Akhunov, A.R.; Gumerov, F.M. Solubility of Water in Supercritical Carbon Dioxide. High Temp. 2002, 40, 203-206. [CrossRef]

24. King, M.B.; Mubarak, A.; Kim, J.D.; Bott, T.R. The mutual solubilities of water with supercritical and liquid carbon dioxides. J. Supercrit. Fluids 1992, 5, 296-302. [CrossRef]

25. Gunstone, F.D. Palm Oil; Critical Reports on Applied Chemistry; John Wiley \& Sons: Chichester, UK, 1987.

26. Birtigh, A.; Johannsen, M.; Brunner, G.; Nair, N. Supercritical-fluid extraction of oil-palm components. J. Supercrit. Fluids 1995, 8, 46-50. [CrossRef]

27. Danielski, L.; Zetzl, C.; Hense, H.; Brunner, G. A process line for the production of raffinated rice oil from rice bran. J. Supercrit. Fluids 2005, 34, 133-141. [CrossRef]

(C) 2019 by the authors. Licensee MDPI, Basel, Switzerland. This article is an open access article distributed under the terms and conditions of the Creative Commons Attribution (CC BY) license (http://creativecommons.org/licenses/by/4.0/). 